\title{
Recombinant Plasminogen Activator Inhibitor-1 Reverses the Bleeding Tendency Associated with the Combined Administration of Tissue-type Plasminogen Activator and Aspirin in Rabbits
}

\author{
Douglas E. Vaughan, Paul J. Declerck, Maria De Mol, and Désiré Collen \\ Center for Thrombosis and Vascular Research, University of Leuven, Leuven, Belgium
}

\begin{abstract}
The major side effect of thrombolytic therapy is bleeding; however, the pathogenesis of this potential complication is not well understood. Accordingly, we examined the effects of aspirin and recombinant human tissue-type plasminogen activator (rtPA) on serial template bleeding times and on hemostasis parameters in rabbits. The administration of intravenous aspirin (15 $\mathrm{mg} / \mathrm{kg}$ ) produced a slight prolongation in bleeding times, from $2.1 \pm 0.5$ to $2.6 \pm 0.5 \mathrm{~min}($ mean $\pm \mathrm{SD}, n=26, P<0.01$ ), whereas $\mathrm{rt}-\mathrm{PA}(1 \mathrm{mg} / \mathrm{kg}$ per $\mathrm{h}$ for $2 \mathrm{~h}$ ) lengthened the bleeding time from $2.4 \pm 0.3$ to $3.2 \pm 0.6 \mathrm{~min}(n=5, P=N S)$. Combination of aspirin with $0.5 \mathrm{mg} / \mathrm{kg}$ per $\mathrm{h}$ of rt-PA for $2 \mathrm{~h}$ prolonged the bleeding time from $2.5 \pm 0.4$ to $6.2 \pm 0.9 \mathrm{~min}(n=10, P$ $<0.01$, with an associated fibrinogen decrease of $\sim 15 \%$. The combination of aspirin with $1 \mathrm{mg} / \mathrm{kg}$ per $\mathrm{h}$ of rt-PA for $2 \mathrm{~h}$ prolonged the bleeding time from $3.0 \pm 0.3$ to $8.3 \pm 1.4 \mathrm{~min}$ ( $n$ $=8, P<0.01$ ) and simultaneously induced a decrease of plasma fibrinogen by $\sim 40 \%$. Virtually all animals treated with rt-PA and aspirin manifested a bleeding tendency, as evidenced by spontaneous rebleeding at sites of previously performed template bleeding times or oozing at the femoral venous catheterization site.

Intravenous bolus injection of $1 \mathrm{mg} / \mathrm{kg}$ of guanidine hydrochloride-reactivated recombinant human plasminogen activator inhibitor-1 (rPAI-1) at the end of the rt-PA infusion resulted in complete reversal, within $5 \mathrm{~min}$, of the prolongation of the bleeding time, and in a disappearance of the bleeding tendency. Nonreactivated rPAI-1 and tranexamic acid were significantly less potent in reversing the bleeding time prolongation.

These findings indicate that aspirin and rt-PA given separately do not markedly affect the template bleeding time, but in combination induce a marked prolongation associated with a significant bleeding tendency. This bleeding time prolongation can be rapidly normalized by the administration of reactivated rPAI-1.
\end{abstract}

During this study D. Vaughan was on leave of absence from the Cardiovascular Division, Brigham and Women's Hospital, Harvard Medical School, Boston, MA.

Address correspondence to Dr. D. Collen, Center for Thrombosis and Vascular Research, Campus Gasthuisberg, $O$ \& N, Herestraat 49, B-3000 Leuven, Belgium.

Received for publication 2 December 1988 and in revised form 21 February 1989

J. Clin. Invest.

(c) The American Society for Clinical Investigation, Inc.

0021-9738/89/08/0586/06 \$2.00

Volume 84, August 1989, 586-591

\section{Introduction}

The major potential complication accompanying the use of recombinant tissue-type plasminogen activator $(\mathrm{rt}-\mathrm{PA})^{1}$ is hemorrhage. Bleeding most commonly occurs at sites where the vascular tree has been penetrated, but occasionally unexpected spontaneous internal or intracranial bleeding may occur. Comparative controlled studies have demonstrated that the administration of rt-PA results in less systemic fibrinogen breakdown than streptokinase $(1,2)$. This fibrinogen-sparing effect of rt-PA does not correlate with a corresponding decrease in hemorrhagic complications (3). Consequently, the parameters responsible for bleeding associated with the administration of rt-PA remain to be identified.

Several observations implicate an rt-PA-mediated effect on platelet function as potentially of major importance in the pathogenesis of the bleeding tendency. Recently, Gimple et al. (4) reported that bleeding time prolongation occurred in $\sim 40 \%$ of a series of patients treated with rt-PA. In these patients the dose of rt-PA and previous aspirin ingestion appeared to correlate significantly with prolongation of the bleeding time, which also appeared to be a relatively powerful predictor of spontaneous bleeding. The validity of this observation is supported by in vitro studies that have demonstrated a diminution in functional platelet activity mediated by rt-PA (5) and potentiated by aspirin (6). Pharmacologic concentrations of rt-PA reduce the aggregation of washed platelets by ADP and thrombin (5) and initiate the dispersal of freshly formed platelet aggregates in aspirin-treated plasma (6).

When critical hemorrhagic complications occur, general measures may be of value, but a specific antidote for rt-PA is not currently available (7). Plasminogen activator inhibitor-1 (PAI-1) is a rapid inhibitor of t-PA, normally occurring at a very low concentration in plasma (8). PAI-1 has been isolated and its cDNA sequenced and expressed through recombinant DNA techniques (9-14). The potential role of this protein in limiting rt-PA-associated hemorrhage or platelet dysfunction has not been investigated.

In this study we examined the effects of the administration of rt-PA and aspirin, alone or in combination, on template bleeding times and bleeding, and the effect of recombinant PAI-1 (rPAI-1) on the bleeding time prolongation.

\section{Methods}

Materials. rt-PA (Actilyse) was provided by Boehringer Ingelheim (Ingelheim, FRG). PAI-1 was expressed and purified from conditioned

1. Abbreviations used in this paper: BT, bleeding time; PAI-1, plasminogen activator inhibitor-1; rPAI-1, recombinant PAI-1; rt-PA, recombinant tissue-type plasminogen activator. 
medium as previously described (14). Aspirin for intravenous administration (Aspegic) was purchased from Synthelabo Benelux (Brussels, Belgium). Tranexamic acid (Exacyl) was from Laboratoires Choay (Paris, France).

Animal model. New Zealand White rabbits, $2.2-2.9 \mathrm{~kg}$ in weight, were anesthetized by the intramuscular injection of $0.4 \mathrm{ml} / \mathrm{kg}$ body weight of Hypnorm (Duphar, Amsterdam, the Netherlands) containing $10 \mathrm{mg} / \mathrm{ml}$ fluanisone and $0.2 \mathrm{mg} / \mathrm{ml}$ fentanyl. A catheter was placed in the right femoral vein for blood sampling. The lateral and medial aspects of both upper hind legs were closely shaved for the performance of serial template bleeding time determinations using a dual blade spring-loaded device (Simplate-II; General Diagnostics, Morris Plains, NJ). The standardized incisions ( $5 \mathrm{~mm}$ long and $1 \mathrm{~mm}$ deep) were made parallel to the long axis of the limb and care was taken to avoid superficial veins. The incision sites were blotted at $\sim 30$-s intervals with filter paper, carefully avoiding contact with the wound. The bleeding time was determined by measuring the time from incision until blood no longer stained the filter paper. In five animals radiolabeled jugular venous thrombi were formed and the extent of thrombolysis quantified as previously described (15).

Treatment groups and experimental protocol. The experimental procedure is schematically depicted in Fig. 1. After an initial template bleeding time determination (BT 1) animals received an intravenous bolus of aspirin $(15 \mathrm{mg} / \mathrm{kg}) .1 \mathrm{~h}$ after the aspirin dose the bleeding time measurement was repeated (BT 2). The animals were then given a continuous infusion of rt-PA through a marginal ear vein. Animals received rt-PA in doses of either 0.5 (group $A$ ) or $1.0 \mathrm{mg} / \mathrm{kg}$ per h (group B) for periods of 2 or $\mathbf{4 h}$. A third bleeding time determination (BT 3) was performed $15 \mathrm{~min}$ before the termination of the rt-PA infusion. Bleeding times 4 and 5 were obtained 5 and 30 min after the end of the rt-PA infusion, respectively. A total of 17 animals received either reactivated rPAI-1 $(n=9)$, nonreactivated rPAI-1 $(n=3)$, or tranexamic acid $(n=5)$ as a bolus injection the first minute after the end of the rt-PA infusion. No specific randomization sequence for administration of these agents was followed and the study was not blinded with respect to the combination of agents given. Venous blood samples were collected on trisodium citrate (final concentration, 0.013 M) simultaneously with the bleeding time determinations. After centrifugation, plasma from these samples was removed and stored at $-20^{\circ} \mathrm{C}$. These samples were used for the measurement of plasma fibrinogen and t-PA-related antigen levels. Eight additional blood samples ( $1.5 \mathrm{ml}$ each) were obtained from the rabbits that received rPAI-1. These were collected in acidified trisodium citrate ( $\mathrm{pH} \mathrm{4.5)}$ and immediately stored on ice (16). Plasma from these samples was obtained by centrifugation at $0^{\circ} \mathrm{C}$ at $2,000 \mathrm{~g}$ for $10 \mathrm{~min}$ and then stored at $-20^{\circ} \mathrm{C}$ until assayed. These acidified samples were used for the measurement of PAI-1 (activity and antigen) and t-PA/PAI-1 complexes.

Analytical methods. Plasma fibrinogen was measured by the Clauss method (17), t-PA- and PAI-1-related antigen levels with specific ELISAs $(16,18)$, and PAI-1 activity by the method of Verheijen et al. (19). t-PA/PAI-1 complex was determined by a sandwich ELISA using a PAI-1-specific MAb (MA-15H12) for capture and a horseradish per-

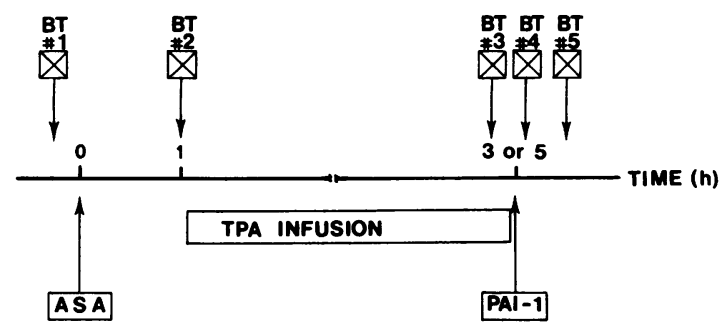

Figure 1. Schematic representation of the experimental procedure for the infusion of aspirin, rt-PA, and/or rPAI-1, and the determination of the template bleeding times. oxidase-conjugated t-PA-specific MAb (MA-62E8) for tagging (20). t-PA activity was measured as previously described (21).

rPAI-1 preparation. IPAI-1 was isolated from conditioned culture media of Chinese hamster ovary cells transfected with the cDNA-encoding human PAI-1 and characterized as previously described (14). This material was virtually inactive but could be reactivated by incubation with guanidine hydrochloride according to the method of Hekman and Loskutoff (22). Material prepared in this manner after extensive dialysis against PBS had a specific activity of $\sim 125,000 \mathrm{U} / \mathrm{mg}$ by titration against the Second International Reference Preparation of t-PA (86/670), obtained from the National Institute for Biological Standards and Control, London, UK. This activity corresponds to $\sim 20 \%$ of the theoretical value for fully active rPAI- 1 on the basis of a specific activity of $500,000 \mathrm{IU} / \mathrm{mg}$ of t-PA and a mol wt of rPAI-1 of $\sim 50,000$.

Statistical analysis. All data are presented as mean \pm SD. The statistical significance of differences within or between groups was determined using $t$ test for paired or unpaired values. $P>0.05$ was considered not significant. Linear regression analyses were performed to examine the correlation between bleeding time prolongation and each of the following: total rt-PA dose, rt-PA level, and residual plasma fibrinogen.

\section{Results}

Effects of aspirin and rt-PA on template bleeding time. Template bleeding times were performed on 26 consecutive rabbits to establish reference values. The bleeding time by this method was $2.1 \pm 0.5 \mathrm{~min}$ (range, $1.25-3.0 \mathrm{~min}$ ) (Fig. $2 \mathrm{~A}$ ). $1 \mathrm{~h}$ after the administration of intravenous aspirin the bleeding time was slightly prolonged, on average by $21 \%$ (to $2.6 \pm 0.5 \mathrm{~min} ; P$ $<0.01$ ) (Fig. $2 B$ ). Infusion of rt-PA alone, at a dose of $1 \mathrm{mg} / \mathrm{kg}$ per $\mathrm{h}$ for $2 \mathrm{~h}$ in five rabbits minimally prolonged the bleeding time (from $2.4 \pm 0.3$ to $3.2 \pm 0.6 \mathrm{~min}, P=\mathrm{NS}$ ) (Fig. $2 C$ ). Infusion of rt-PA at a dose of $0.5 \mathrm{mg} / \mathrm{kg}$ per $\mathrm{h}$ for $2 \mathrm{~h}$ to aspirintreated rabbits produced $62 \pm 11 \%$ lysis of ${ }^{125} \mathrm{I}$-fibrin-labeled clots in the jugular vein as determined in five animals.

The administration of rt-PA to aspirin-treated animals at a dose of $0.5 \mathrm{mg} / \mathrm{kg}$ per $\mathrm{h}$ for $2 \mathrm{~h}$ prolonged the bleeding time

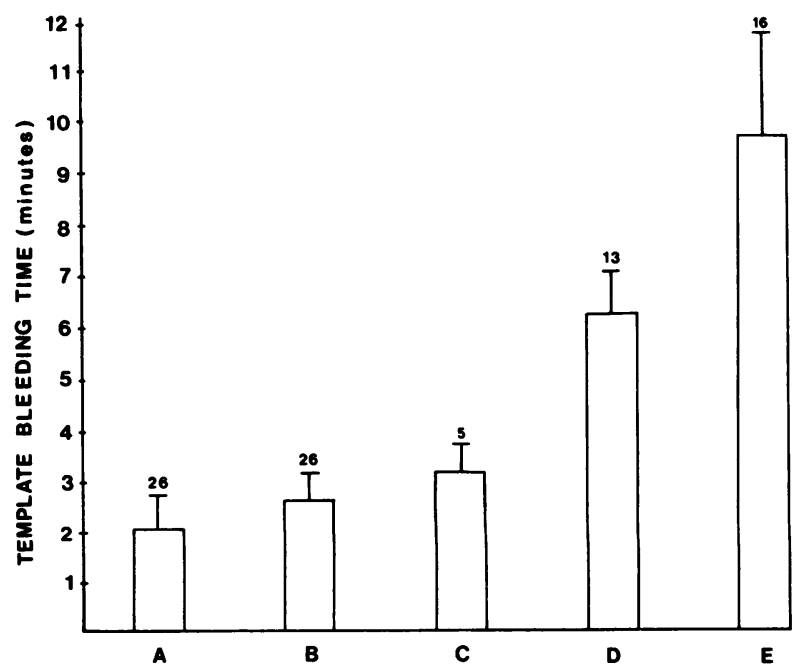

Figure 2. Template bleeding times. $(A)$ Baseline values; $(B) 1 \mathrm{~h}$ after aspirin injection; $(C)$ at the end of $\mathrm{rt}-\mathrm{PA}$ infusion $(1 \mathrm{mg} / \mathrm{kg}$ per $\mathrm{h}$ for $2 \mathrm{~h}) ;(D)$ at the end of rt-PA infusion $(0.5 \mathrm{mg} / \mathrm{kg}$ per $\mathrm{h}$ for 2 or $4 \mathrm{~h})$ in aspirin-treated rabbits; $(E)$ at the end of rt-PA infusion $(1 \mathrm{mg} / \mathrm{kg}$ per $h$ for 2 or $4 h$ ) in aspirin-treated rabbits. The numbers represent the group sizes and the vertical bars represent SD. 
from $2.5 \pm 0.4$ to $6.2 \pm 0.9 \mathrm{~min}(n=10, P<0.01)$. With 0.5 $\mathrm{mg} / \mathrm{kg}$ per $\mathrm{h}$ for $4 \mathrm{~h}$ the bleeding time was prolonged from $2.4 \pm 0.4$ to $6.7 \pm 1.0 \mathrm{~min}(n=3, P<0.01)$. The values of the combined groups are illustrated in Fig. $2 D$. Infusion of rt-PA at a dose of $1 \mathrm{mg} / \mathrm{kg}$ per $\mathrm{h}$ for $2 \mathrm{~h}$ in aspirin-treated rabbits caused a prolongation of the template bleeding time from $3.0 \pm 0.3$ to $8.3 \pm 1.4 \mathrm{~min}(n=8, P<0.01)$. An rt-PA dose of 1 $\mathrm{mg} / \mathrm{kg}$ per $\mathrm{h}$ for $4 \mathrm{~h}$ resulted in a bleeding time of $10.6 \pm 2.5 \mathrm{~min}$ ( $n=8, P<0.01$ vs. a baseline value of $2.9 \pm 0.5 \mathrm{~min}$ ). The values of the combined groups are illustrated in Fig. $2 E$.

The bleeding times remained significantly prolonged 30 min after the end of the rt-PA infusion in aspirin-treated rabbits (Fig. 3). In the group given $0.5 \mathrm{mg} / \mathrm{kg}$ per $\mathrm{h}$ of rt-PA the bleeding time averaged $5.8 \pm 0.7(n=6) \mathrm{min}$ at $15 \mathrm{~min}$ before the end of the rt-PA infusion, $7.3 \pm 2.5 \mathrm{~min}(n=5) 5 \mathrm{~min}$ after the end of rt-PA infusion in animals without rPAI-1 or tranexamic acid administration, and $6.3 \pm 1.0 \mathrm{~min}(n=5)$ after 30 min (Fig. $3 A$, part 1 ). In the group given $1 \mathrm{mg} / \mathrm{kg}$ per h rt-PA the animals exhibited a similar pattern of bleeding time prolongation in the absence of rPAI- 1 or tranexamic acid administration, averaging $9.6 \pm 2.2 \mathrm{~min}(n=5) 15 \mathrm{~min}$ before the end of the rt-PA infusion $(n=5), 8.4 \pm 1.7 \mathrm{~min}(n=4) 5 \mathrm{~min}$ post-rt-PA, and $8.9 \pm 0.9 \mathrm{~min}(n=3)$ after $30 \mathrm{~min}$ (Fig. $3 \mathrm{~B}$, part 1).

The development of a bleeding tendency, defined as spontaneous bleeding from the femoral vein catheterization site or recurrent bleeding from template incision sites, was observed in 28 of $29(97 \%)$ animals treated with the combination of rt-PA and aspirin, while mild oozing was noted in only 1 of 5 animals that received rt-PA without aspirin.

Effects of rt-PA and aspirin on hemostasis parameters. Table I summarizes results of template bleeding times, hemostasis parameters, and the incidence of spontaneous bleeding in relation to rt-PA dose and duration of infusion in aspirinand non-aspirin-treated rabbits. Infusion of rt-PA at a dose of $0.5 \mathrm{mg} / \mathrm{kg}$ per $\mathrm{h}$ for $2 \mathrm{~h}$ resulted in a plasma level of rt-PA in blood obtained $15 \mathrm{~min}$ before the termination of the rt-PA infusion of $1.0 \pm 0.5 \mu \mathrm{g} / \mathrm{ml}$. This was associated with a mild decrease in plasma fibrinogen level. Infusion of rt-PA at a dose of $1 \mathrm{mg} / \mathrm{kg}$ per $\mathrm{h}$ for $2 \mathrm{~h}$, resulting in a plasma level of $2.6 \pm 1.0$ $\mu \mathrm{g} / \mathrm{ml}$, caused more extensive systemic fibrinolytic activation, with residual fibrinogen levels of $63 \pm 21 \%$. Infusion of the same dose of rt-PA $(1 \mathrm{mg} / \mathrm{kg}$ per h) over $4 \mathrm{~h}$ produced somewhat more extensive fibrinogen breakdown. Linear regression analysis revealed a significant correlation between bleeding time in aspirin-treated rabbits and total rt-PA dose $(r=0.71, P$ $<0.01)$ and residual fibrinogen level $(r=0.61, P<0.01)$. Plasma rt-PA level correlated less well with the bleeding time $(r$ $=0.31, P=0.1$ ).

Effects of rPAI-1 and tranexamic acid on the bleeding time. Reactivated rPAI-1 was administered as a bolus injection of 1 $\mathrm{mg} / \mathrm{kg}$ (total protein) in a volume of 5-8 ml over $1 \mathrm{~min}$ to six rabbits in group A (given $0.5 \mathrm{mg} / \mathrm{kg}$ per h of rt-PA), which reduced the bleeding time from $6.5 \pm 0.7 \mathrm{~min}$ before injection to $2.8 \pm 0.7 \mathrm{~min}(P<0.01) 5 \mathrm{~min}$ after injection and $2.6 \pm 0.6$ $\min (P<0.01) 30 \mathrm{~min}$ after injection (Fig. $3 A$, part 2$)$. The reference bleeding time in these six rabbits $(1 \mathrm{~h}$ post-aspirin and before the initiation of the rt-PA infusion) was $2.6 \pm 0.3$ min. In three rabbits of group B (given $1 \mathrm{mg} / \mathrm{kg}$ per h of rt-PA) injection of reactivated $\mathrm{rPAI}-1$ reduced the bleeding time from $12.2 \pm 2.5 \mathrm{~min}$ before to $3.1 \pm 0.4 \mathrm{~min}(P<0.01) 5 \mathrm{~min}$ after injection and $3.1 \pm 0.2 \mathrm{~min}(P<0.01) 30 \mathrm{~min}$ after injection
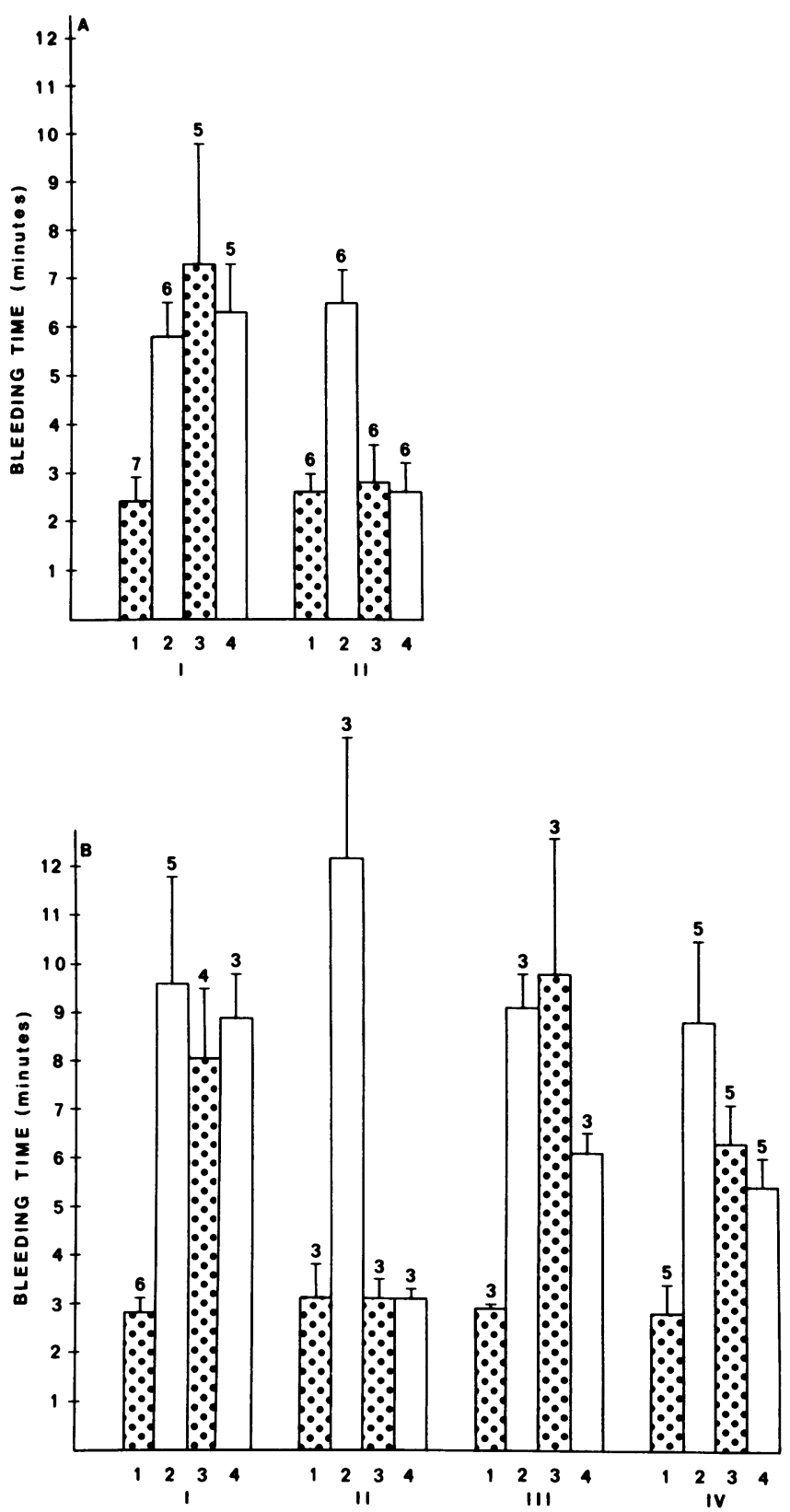

Figure 3. Template bleeding times. (A) Aspirin-treated rabbits infused with $0.5 \mathrm{mg} / \mathrm{kg}$ per $\mathrm{h}$ of rt-PA; $(B)$ aspirin-treated rabbits infused with $1 \mathrm{mg} / \mathrm{kg}$ per $\mathrm{h}$ of rt-PA. $1,1 \mathrm{~h}$ post-aspirin and immediately before initiation of rt-PA infusion (baseline); 2, $15 \mathrm{~min}$ before the end of the rt-PA infusion; 3, 5 min after the end of the rt-PA infusion; 4, $30 \mathrm{~min}$ after the end of the rt-PA infusion; $I$, without rPAI-1 injection; $I I$, with injection of $1 \mathrm{mg} / \mathrm{kg}$ guanidine hydrochloride reactivated $\mathrm{rPAI}-1 ; I I I$, with injection of $1 \mathrm{mg} / \mathrm{kg}$ nonreactivated rPAI-1; $I V$, with injection of $100 \mathrm{mg} / \mathrm{kg}$ tranexamic acid.

(Fig. $3 \dot{B}$, part 2). These posttreatment values are not significantly different from the baseline bleeding times of $3.1 \pm 0.7$ min. As illustrated in Table II, injection of reactivated PAI-1 reversed the bleeding time prolongation in all animals to near baseline values and quickly reversed spontaneous bleeding.

The administration of an equivalent amount of nonreactivated rPAI-1 in three rabbits did not modify the bleeding time within $5 \mathrm{~min}$ after injection $(9.1 \pm 0.7$ and $9.8 \pm 2.8 \mathrm{~min}$, respectively). Partial reversal of the bleeding time prolongation was 
Table I. Hemostasis Parameters and Incidence of Spontaneous Bleeding during rt-PA Infusions

\begin{tabular}{|c|c|c|c|c|c|c|c|}
\hline \multicolumn{3}{|c|}{ Treatment groups } & \multirow[b]{3}{*}{$n$} & \multirow[b]{3}{*}{ Bleeding time } & \multirow[b]{3}{*}{$\mathrm{rt}-\mathrm{PA}$ levels } & \multirow{3}{*}{$\begin{array}{c}\text { Residual } \\
\text { fibrinogen }\end{array}$} & \multirow{3}{*}{$\begin{array}{c}\text { Spontaneou } \\
\text { bleeding }\end{array}$} \\
\hline \multirow[b]{2}{*}{ Aspirin } & \multicolumn{2}{|c|}{$\mathrm{rt}-\mathrm{PA}$} & & & & & \\
\hline & Dose & Duration & & & & & \\
\hline & $m g / k g$ per $h$ & $h$ & & $\min$ & $\mu g / m l$ & $\%$ & $n / n$ \\
\hline Yes & 0.5 & 2 & 10 & $6.2 \pm 0.9$ & $1.0 \pm 0.5$ & $87 \pm 24$ & $9 / 10$ \\
\hline Yes & & 4 & 3 & $6.7 \pm 0.9$ & $1.5 \pm 0.4$ & $62 \pm 40$ & $3 / 3$ \\
\hline Yes & 1.0 & 2 & 8 & $8.3 \pm 1.4$ & $2.6 \pm 1.0$ & $63 \pm 21$ & $8 / 8$ \\
\hline Yes & & 4 & 8 & $10.6 \pm 2.5$ & $3.4 \pm 2.3$ & $42 \pm 18$ & $8 / 8$ \\
\hline No & 1.0 & 2 & 5 & $3.2 \pm 0.6$ & $2.2 \pm 0.6$ & $60 \pm 22$ & $1 / 5$ \\
\hline
\end{tabular}

The bleeding time and rt-PA plasma levels were determined $15 \mathrm{~min}$ before the discontinuation of the rt-PA infusions. Residual fibrinogen levels are expressed as a percentage of baseline values. Spontaneous bleeding was defined as the oozing at the femoral venous catheterization site or recurrent bleeding at sites of previously performed template bleeding times. The data are presented as mean \pm SD.

observed after $30 \mathrm{~min}$ in these animals $(6.1 \pm 0.4 \mathrm{~min}, P<0.05)$ (Fig. $3 B$, part 3). The administration of tranexamic acid (100 $\mathrm{mg} / \mathrm{kg}$ ) in five animals that had received aspirin and $1 \mathrm{mg} / \mathrm{kg}$ per $h$ of rt-PA produced a partial reversal of the bleeding time prolongation from $8.8 \pm 1.3 \mathrm{~min}$ before to $6.3 \pm 0.8 \mathrm{~min}$ after 5 $\min (P<0.05)$, and to $5.4 \pm 0.6 \mathrm{~min}$ after $30 \mathrm{~min}(P<0.01)$ (Fig. $3 B$, part 4 ).

The bleeding tendency was reversed by all three agents, albeit much more quickly by reactivated rPAI-1 (Table II). Cessation of spontaneous bleeding was observed within $2.2 \pm 1.6 \min (n=9)$ after the administration of reactivated
rPAI-1. This was significantly faster $(P<0.001)$ than with tranexamic acid $(11.7 \pm 6 \mathrm{~min})(n=5)$ or with nonreactivated rPAI-1 $(12.5 \pm 7 \mathrm{~min})(n=3)$.

Plasma clearance of rPAI-1 antigen and rt-PA/rPAI-1 complex. The rPAI-1 antigen level in plasma after bolus injection was $14 \pm 10 \mu \mathrm{g} / \mathrm{ml}$. Its disappearance could be described by a sum of two exponential terms with a terminal $t_{1 / 2}$ of $15 \mathrm{~min}$ and an initial $t_{1 / 2}$ of $<3 \mathrm{~min}$. Free rPAI- 1 activity was measurable in plasma $1 \mathrm{~min}$ after injection of the reactivated protein and averaged $1,200 \pm 720 \mathrm{U} / \mathrm{ml}(n=7)$. No free t-PA was detectable in these animals. t-PA/PAI-1 complexes were

Table II. Effects of Reactivated or Latent rPAI-1 and Tranexamic Acid on Bleeding Time Prolongation

\begin{tabular}{|c|c|c|c|c|c|c|c|c|c|}
\hline \multirow{2}{*}{$\begin{array}{l}\text { Animal } \\
\text { No. }\end{array}$} & \multirow[b]{2}{*}{ Dose } & \multicolumn{2}{|c|}{$\mathrm{rt}-\mathrm{PA}$} & \multirow[b]{2}{*}{ Aspirin } & \multicolumn{4}{|c|}{ Bleeding time } & \multirow{2}{*}{$\begin{array}{l}\text { Time to cessation } \\
\text { of spontaneous bleeding }\end{array}$} \\
\hline & & I & Duration & & Baseline & $-15 \min$ & $+5 \min$ & $+30 \mathrm{~min}$ & \\
\hline & \multicolumn{2}{|l|}{$m g / k g$ per $h$} & $h$ & & \multicolumn{4}{|c|}{$\min$} & $\min$ \\
\hline \multicolumn{10}{|c|}{ Reactivated rPAI-1 } \\
\hline 1 & 0.5 & I & 2 & + & 2.5 & 6.8 & 2.1 & 2.6 & 2 \\
\hline 2 & 0.5 & I & 2 & + & 2.4 & 6.3 & 3.5 & 3.0 & 5 \\
\hline 3 & 0.5 & I & 2 & + & 3.0 & 6.0 & 2.6 & 2.9 & 2.5 \\
\hline 4 & 0.5 & I & 2 & + & 2.2 & 5.7 & 3.5 & 3.0 & - \\
\hline 5 & 0.5 & I & 4 & + & 2.8 & 6.3 & 3.1 & 2.5 & 1.5 \\
\hline 6 & 0.5 & I & 4 & + & 2.4 & 7.8 & 1.8 & 1.5 & 0.8 \\
\hline 7 & 1.0 & I & 4 & + & 2.2 & 14.5 & 3.3 & 3.0 & 0.5 \\
\hline 8 & 1.0 & I & 4 & + & 3.5 & 9.5 & 2.6 & 3.7 & 1.0 \\
\hline 9 & 1.0 & I & 4 & + & 3.7 & 12.5 & 3.4 & 3.0 & 2.0 \\
\hline \multicolumn{10}{|c|}{ Latent rPAI-1 } \\
\hline 10 & 1.0 & I & 2 & + & 3.0 & 9.0 & 13.0 & 6.0 & 20.0 \\
\hline 11 & 1.0 & I & 2 & + & 2.8 & 9.8 & 8.5 & 5.8 & 7.5 \\
\hline 12 & 1.0 & I & 2 & + & 3.0 & 8.5 & 7.8 & 6.5 & 10.0 \\
\hline \multicolumn{10}{|c|}{ Tranexamic acid } \\
\hline 13 & 1.0 & I & 2 & + & 3.0 & 9.0 & 6.5 & 5.0 & 6.5 \\
\hline 14 & 1.0 & I & 2 & + & 2.0 & 8.0 & 5.8 & 5.0 & 15.0 \\
\hline 15 & 1.0 & I & 2 & + & 3.5 & 9.3 & 6.0 & 4.8 & 5.0 \\
\hline 16 & 1.0 & I & 2 & + & 3.0 & 10.3 & 7.5 & 6.0 & 12.0 \\
\hline 17 & 1.0 & I & 2 & + & 2.5 & 9.5 & 5.5 & 6.0 & 20.0 \\
\hline
\end{tabular}

The baseline bleeding time was determined $1 \mathrm{~h}$ post-aspirin $(15 \mathrm{mg} / \mathrm{kg}$ i.v. $)$ and immediately before initiation of the rt-PA infusion. The $-15-$ min bleeding time was obtained 15 min before termination of the rt-PA infusion, and the $+15-$ and +30 -min determinations were performed 5 or $30 \mathrm{~min}$ after the termination of rt-PA and after the bolus injection of rPAI-1 or tranexamic acid. 
cleared at a rate very similar to total rPAI-1 antigen (not shown). After the administration of nonreactivated rPAI-1 or tranexamic acid, free rt-PA activity remained detectable in all animals. It decreased from $770 \pm 570 \mathrm{U} / \mathrm{ml}$ before to $34 \pm 10$ $\mathrm{U} / \mathrm{ml}$ after $5 \mathrm{~min}$ and to $9 \pm 1 \mathrm{U} / \mathrm{ml}$ after $30 \mathrm{~min}$ after injection of nonreactivated rPAI- 1 in three rabbits and from $440 \pm 43$ $\mathrm{U} / \mathrm{ml}$ before to $57 \pm 9 \mathrm{U} / \mathrm{ml}$ after $5 \mathrm{~min}$ and $19 \pm 6 \mathrm{U} / \mathrm{ml}$ after $30 \mathrm{~min}$ in five rabbits given tranexamic acid.

\section{Discussion}

The pathogenesis of the bleeding tendency associated with thrombolytic therapy remains largely unknown. The extent of fibrinogen breakdown does not appear to be the primary determinant for spontaneous bleeding (1-3). Furthermore, the effects of thrombolytic therapy on platelet function remain controversial, as both hypo- and hyperaggregability of platelets in the presence of fibrinolytic agents and/or plasmin have been reported $(5,6,23-27)$.

Template bleeding times appear to be a potentially useful surrogate endpoint for quantitation of the bleeding tendency associated with rt-PA administration. In a pilot study in patients with acute myocardial infarction treated with rt-PA, bleeding time prolongation predicted spontaneous bleeding with a sensitivity and specificity of $\sim 70 \%$ (4). The potentiating effect of aspirin, which was suggested by the correlation of bleeding time prolongation with aspirin ingestion and dose of rt-PA, was recently confirmed in an experimental study in dogs (Gold, H. K., personal communication).

In the present study we have confirmed and extended these observations in rabbits. Separate administration of either aspirin or rt-PA did not markedly prolong the bleeding time, whereas their combined administration resulted in both a marked prolongation of the template bleeding time and the development of a pronounced bleeding tendency. This bleeding time prolongation was observed in the presence of only moderate fibrinogen degradation, confirming that the systemic fibrinolytic state per se is not the primary determinant of bleeding. Furthermore, in animals treated with $1 \mathrm{mg} / \mathrm{kg}$ per $\mathrm{h}$ of rt-PA alone we did not observe a significant increase in the mean bleeding time even though fibrinogen levels fell an average of $40 \%$.

The bleeding tendency induced by the combination of rt-PA and aspirin in vivo appears to be readily reversible by the administration of reactivated rPAI-1. This suggests that the combined administration of aspirin and rt-PA does not irreversibly alter the functional capacity of circulating platelets. This is in agreement with previous observations that platelets retain the capacity to aggregate when reexposed to ADP after a prior exposure to disaggregating concentrations of rt-PA in vitro (6). Furthermore, rt-PA does not appear to alter the membrane glycoproteins of platelets in plasma or affect fibrinogen binding to platelets, but instead induces plasminmediated proteolysis of surface-bound cohesive fibrinogen (6).

The rabbits in our study had circulating rt-PA levels well in excess of a threshold concentration of $0.5 \mu \mathrm{g} / \mathrm{ml}$ at which disaggregation of aspirin-treated platelets has been observed (6). In turn, this may have initiated the breakdown of newly formed hemostatic plugs, which may partially explain the observed prolongation in bleeding times. Additionally, it has recently been reported that rt-PA binds to endothelial cells in culture (28) and, once bound, retains its catalytic efficiency. The relative contribution of cell-surface bound rt-PA to hemo- stasis is unknown, but theoretically it may play a role in the bleeding time prolongation as well.

Whether or not aspirin has a similar effect on the bleeding time and induces a hemorrhagic tendency when combined with other plasminogen activators than rt-PA is not well documented. Streptokinase given alone has been reported to lengthen the bleeding time in rabbits (24). However, streptokinase has also been reported to activate platelets in vivo (23), and to be less potent at promoting platelet disaggregation than rt-PA in vitro (29). Furthermore, a recent report has described an apparent beneficial therapeutic interaction between aspirin and streptokinase in patients with acute myocardial infarction (30) without a marked associated increased incidence of hemorrhagic complications.

The ability of rPAI-1 to correct the bleeding tendency associated with the administration of rt-PA suggests that rPAI-1 may be of value as a specific antidote for bleeding complications associated with the use of rt-PA. Reactivated rPAI-1 appears to be more potent for the reversal of the bleeding time prolongation associated with rt-PA infusion than tranexamic acid, a synthetic, nonphysiologic inhibitor of fibrinolysis. Clinical situations where an antidote for rt-PA may be useful include patients with uncontrollable or catastrophic hemorrhage, overdosage (inadvertently or otherwise), or when rt-PA is administered to patients with incorrect diagnosis of acute myocardial infarction (e.g., aortic dissection or pericarditis).

Several important issues, of both a theoretical and technical nature, must be addressed before rPAI-1 may be considered for administration to humans. Elevated levels of PAI-1 have been implicated in the pathogenesis of thromboembolic disease $(31,32)$; whether or not the administration of rPAI-1 will promote thrombosis or the reocclusion of a recanalized coronary artery is unknown. The PAI-1 protein produced through recombinant DNA techniques is usually obtained in a biologically inactive conformation (9-14) and exposure to protein denaturants, such as urea or guanidine hydrochloride (22), or to negatively charged phospholipids (33) is necessary for its reactivation. Interestingly, we also observed a significant decrease in the bleeding time after $30 \mathrm{~min}$ in three animals that received latent rPAI-1. Although not conclusively demonstrated at this stage, one could speculate that this may have occurred as the result of reactivation of latent rPAI-1 in vivo. This may be relevant in view of the fact that denaturant-induced reactivation of the protein is relatively short lived (34). Another problem with the potential use of rPAI-1 in patients may be sensitivity of the methionine residue located at the P1' site in its reactive center to oxidation (35) which also causes inactivation of the molecule. Notwithstanding these limitations, rPAI- 1 constitutes a valuable tool for investigation of the hemostatic perturbations that contribute to the bleeding tendency associated with the administration of rt-PA.

\section{Acknowledgments}

This work was supported by grants from the Geconcerteerde Onderzoeksacties (project 85-90/78). P. J. Declerck is a Senior Research Assistant of the National Fund for Scientific Research, Belgium.

\section{References}

1. Collen, D., H. Bounameaux, F. De Cock, H. R. Lijnen, and M. Verstraete. 1986. Analysis of coagulation and fibrinolysis during intravenous infusion of recombinant human tissue-type plasminogen acti- 
vator in patients with acute myocardial infarction. Circulation. 73:511-517.

2. Rao, A. K., C. Pratt, A. Berke, A. Jaffe, I. Ockene, T. L. Schreiber, W. R. Bell, G. Knatterud, T. L. Robertson, and M. L. Terrin. 1988. Thrombolysis in myocardial infarction (TIMI) trial phase I: hemorrhagic manifestations and changes in plasma fibrinogen and the fibrinolytic system in patients treated with recombinant tissue plasminogen activator and streptokinase. J. Am. Coll. Cardiol. 11:1-11.

3. Califf, R. M., E. J. Topol, B. S. George, J. M. Boswick, C. Abbottsmith, K. W. Sigmon, R. Candela, R. Masek, D. Kereiakis, W. W. O'Neill, R. S. Stack, and D. Stump. 1988. Hemorrhagic complications associated with the use of intravenous tissue plasminogen activator in the treatment of acute myocardial infarction. Am. J. Med. 85:353-359.

4. Gimple, L. W., H. K. Gold, R. C. Leinbach, T. Yasuda, J. A. Johns, A. A. Ziskind, and D. Collen. 1988. Bleeding time measurement predicts spontaneous bleeding during thrombolysis with recombinant tissue-type plasminogen activator (rt-PA). J. Am. Coll. Cardiol. 11(Suppl A):231 A. (Abstr.)

5. Stricker, R. B., D. Wong, D. T. Shiu, P. T. Reyes, and M. A. Shuman. 1986. Activation of plasminogen by tissue plasminogen activator on normal and thrombasthenic platelets. Effects on surface proteins and platelet aggregation. Blood. 68:275-280.

6. Loscalzo, J., and D. E. Vaughan. 1987. Tissue plasminogen activator promotes platelet disaggregation in plasma. J. Clin. Invest. 79:1749-1755.

7. Loscalzo, J., and E. Braunwald. 1988. Tissue plasminogen activator. N. Engl. J. Med. 319:925-931.

8. Kruithof, E. K. O., C. Tran-Thang, A. Ransijn, and F. Bachmann. 1984. Demonstration of a fast-acting inhibitor of plasminogen activators in human plasma. Blood. 64:907-913.

9. Ginsburg, D., R. Zeheb, A. Y. Yang, U. M. Raferty, P. A. Andreasen, L. Nielsen, K. Dano, R. V. Lebo, and T. D. Gelehrter. 1986. cDNA cloning of human plasminogen activator-inhibitor from endothelial cells. J. Clin. Invest. 78:1673-1680.

10. Pannekoek, H., H. Veerman, H. Lambers, P. Diergaarde, C. L. Verweij, A.-J. van Zonneveld, and J. A. van Mourik. 1986. Endothelial plasminogen activator inhibitor (PAI): a new member of the Serpin gene family. EMBO (Eur. Mol. Biol. Organ.) J. 5:2539-2544.

11. Andreasen, P. A., A. Riccio, K. G. Welinder, R. Douglas, R. Sartorio, L. S. Nielsen, C. Oppenheimer, F. Blasi, and K. Dano. 1986. Plasminogen activator inhibitor type-1: reactive center and amino-terminal heterogeneity determined by protein and cDNA sequencing. FEBS (Fed. Eur. Biochem. Soc.) Lett. 209:213-218.

12. Ny, T., M. Sawdey, D. Lawrence, J. L. Millan, and D. J. Loskutoff. 1986. Cloning and sequence of a cDNA coding for the human $\beta$-migrating endothelial-cell-type plasminogen activator inhibitor. Proc. Natl. Acad. Sci. USA. 83:6776-6780.

13. Wun, T. C., and K. K. Kretzmer. 1987. cDNA cloning and expression in $E$. coli of a plasminogen activator inhibitor (PAI) related to a PAI produced by HepG2 hepatoma cell. FEBS (Fed. Eur. Biochem. Soc.) Lett. 210:11-16.

14. Alessi, M. C., P. J. Declerck, M. De Mol, L. Nelles, and D. Collen. 1988. Purification and characterization of natural and recombinant human plasminogen activator inhibitor-1 (PAI-1). Eur. J. Biochem. 175:531-540.

15. Collen, D., J. M. Stassen, and M. Verstraete. 1983. Thrombolysis with human extrinsic (tissue-type) plasminogen activator in rabbits with experimental jugular vein thrombosis. Effect of molecular form and dose of activator, age of the thrombus, and route of administration. J. Clin. Invest. 71:368-376.

16. Declerck, P. J., M. C. Alessi, M. Verstreken, E. K. O. Kruithof, I. Juhan-Vague, and D. Collen. 1988. Measurement of plasminogen activator inhibitor 1 in biologic fluids with a murine monoclonal antibody-based enzyme-linked immunosorbent assay. Blood. 71:220-225.
17. Clauss, A. 1957. Gerinnungsphysiologische Schnellmethode zur Bestimmung des Fibrinogens. Acta Haematol. (Basel). 17:237246.

18. Holvoet, P., H. Cleemput, and D. Collen. 1985. Assay of human tissue-type plasminogen activator (t-PA) with an enzymelinked immunosorbent assay (ELISA) based on three murine monoclonal antibodies to t-PA. Thromb. Haemostasis. 54:684-687.

19. Verheijen, J. H., G. T. G. Chang, and C. Kluft. 1984. Evidence for the occurrence of a fast-acting inhibitor for tissue-type plasminogen activator in human plasma. Thromb. Haemostasis. 51:392-395.

20. Declerck, P. J., M. Verstreken, and D. Collen. 1987. An immunofunctional assay for active plasminogen activator inhibitor-1 (PAI-1). Fibrinolysis 2(Suppl 2):77-78.

21. Verheijen, J. H., E. Mullaert, G. T. G. Chang, C. Kluft, and G. Wijngaards. 1982. A simple, sensitive spectrophotometric assay for extrinsic (tissue-type) plasminogen activator applicable to measurement in plasma. Thromb. Haemostasis. 48:266-269.

22. Hekman, C. M., and D. J. Loskutoff. 1985. Endothelial cells produce a latent inhibitor of plasminogen activators than can be activated by denaturants. J. Biol. Chem. 260:11581-11587.

23. Fitzgerald, D. J., F. Catella, L. Roy, and G. A. FitzGerald. 1988. Marked platelet activation in vivo after intravenous streptokinase in patients with acute myocardial infarction. Circulation. 77:142-150.

24. Niewiarowski, S., A. F. Senyl, and D. Gillies. 1973. Plasmininduced platelet aggregation and platelet release reaction. J. Clin. Invest. 52:1647-1659.

25. Schafer, A. I., and B. Adelman. 1985. Plasmin inhibition of platelet function and of arachidonic acid metabolism. J. Clin. Invest. 75:456-461.

26. Ohlstein, E. H., B. Storer, T. Fujita, and R. J. Shebuski. 1987. Tissue-type plasminogen activator and streptokinase induce platelet hyperaggregability in the rabbit. Thromb. Res. 76:575-585.

27. Guccione, M. A., R. L. Kinlough-Rathbone, M. A. Packham, E. J. Harfenist, M. L. Rand, J. P. Greenberg, D. W. Perry, and J. R. Mustard. 1985. Effects of plasmin on rabbit platelets. Thromb. Haemostasis. 53:8-14.

28. Hajjar, K. A., N. M. Hamel, P. C. Harpel, and R. L. Nachman. 1987. Binding of tissue plasminogen activator to cultured human endothelial cells. J. Clin. Invest. 80:1712-1719.

29. Vaughan, D. E., and J. Loscalzo. 1986. Disaggregation of platelets: a comparison of tissue plasminogen activator, streptokinase, and urokinase. Circulation. 74:II-95. (Abstr.)

30. ISIS-2 (second international study of infarct survival) Collaborative Group. 1988. A randomized trial of intravenous streptokinase, oral aspirin, both or neither among 17,187 cases of suspected acute myocardial infarction: ISIS-2. Lancet. ii:349-360.

31. Wiman, B., B. Ljundberg, J. Chmielewska, G. Urdén, M. Blombäck, and H. Johnsson. 1985. The role of the fibrinolytic system in deep vein thrombosis. J. Lab. Clin. Med. 105:265-270.

32. Hamsten, A., B. Wiman, U. De Faire, and M. Blombäck. 1985. Increased levels of a rapid inhibitor of tissue plasminogen activator in young survivors of acute myocardial infarction. N. Engl. J. Med. 313:1557-1563.

33. Lambers, J. M. J., M. Cammenga, B. W. König, K. Mertens, H. Pannekoek, and J. A. Van Mourik. 1987. Activation of human endothelial cell-type plasminogen activator inhibitor (PAI-1) by negatively charged phospholipids. J. Biol. Chem. 262:17492-17496.

34. Declerck, P. J., M. De Mol, M. C. Alessi, S. Baudner, E. P. Pâques, K. T. Preisner, G. Müller-Berghaus, and D. Collen. 1988. Purification and characterization of a plasminogen activator inhibitor 1 binding protein from human plasma: identification as a multimeric form of S protein (vitronectin). J. Biol. Chem. 263:15454-15461.

35. Lawrence, D. A., and D. J. Loskutoff. 1986. Inactivation of plasminogen activator inhibitor by oxidants. Biochemistry. 25:63516355. 